\title{
Anthracnose control of 'Prata-Anã' banana with pre-harvest phosphite application
}

\author{
Maria Luísa Mendes Rodrigues ${ }^{1}$, Samuel Gustavo Ribeiro de Souza ${ }^{2}$, Edson Hiydu Mizobutsi ${ }^{3}$, \\ Juceliandy Mendes da Silva Pinheiro ${ }^{3}$, Flávio Pinto Monção ${ }^{4}$, Gisele Polete Mizobutsi ${ }^{3}$
}

\begin{abstract}
The aim of this study was to evaluate the anthracnose intensity in 'Prata-Anã' banana with the application of three phosphite formulations in two application intervals in the developing banana bunches and to evaluate the physical and chemical characteristics of fruits. In the field, in addition to producer management, three phosphite formulations were evaluated: FCu1 $(4 \% \mathrm{Cu}$ $\left.+20 \% \mathrm{P}_{2} \mathrm{O}_{5}\right), \mathrm{FCu} 2\left(4 \% \mathrm{Cu}+22 \% \mathrm{P}_{2} \mathrm{O}_{5}\right)$ and $\mathrm{FK}\left(42 \% \mathrm{P}_{2} \mathrm{O}_{5}+27.7 \% \mathrm{~K} 2 \mathrm{O}\right)$ sprayed on banana bunches at different application frequencies: four and eight times. The experiment was carried out in a randomized blocks design following a $5 \times 2$ factorial scheme, with 3 phosphite formulations, pure water and no application and two application intervals. Pure water and no application were used as control. Fruits were harvested, stored in refrigeration chamber $\left(25 \pm 1^{\circ} \mathrm{C}\right.$ and $\left.80 \pm 5 \% \mathrm{RH}\right)$ and evaluated for anthracnose incidence and severity, as well as physical and chemical characteristics. The application of copper phosphite can control anthracnose incidence by $38 \%$ and severity by $49.5 \%$. The frequency of phosphite application does not affect anthracnose intensity. FCu1 phosphite application in 'Prata-Anã' banana bunches, as well as eight phosphite applications increases fresh mass loss. Phosphite application frequency affected the chemical characteristics of banana fruits. Index terms: Colletotrichum musae, severity, Musa spp., phosphites, treatment.
\end{abstract}

\section{Controle da antracnose da banana 'Prata-Anã' com aplicação de fosfito em pré-colheita}

Corresponding author: marialuisamendes@yahoo.com.br

Received:November 12, 2019 Accepted: April 09, 2020

Copyright: All the contents of this journal, except where otherwise noted, is licensed under a Creative Commons Attribution License.

\section{$(\mathrm{cc}) \mathrm{EY}$}

Resumo - O objetivo do trabalho foi avaliar a intensidade de antracnose em banana 'Prata-Anã' com aplicação de três formulações de fosfito, em dois intervalos de aplicação nos cachos da bananeira em desenvolvimento, e avaliar as características físicas e químicas dos frutos. No campo, em adição ao manejo do produtor, foram avaliadas três formulações de fosfito: $\mathrm{FCu} 1(4 \% \mathrm{de} \mathrm{Cu}+20 \%$ de $\left.\mathrm{P}_{2} \mathrm{O}_{5}\right)$ FCu2 $\left(4 \%\right.$ de $\mathrm{Cu}+22 \%$ de $\mathrm{P}_{2} \mathrm{O}_{5)}$ e FK $\left(42 \%\right.$ de $\mathrm{P}_{2} \mathrm{O}_{5+} 27,7 \%$ de $\left.\mathrm{K}_{2} \mathrm{O}\right)$ pulverizados nos cachos da bananeira, em diferentes frequências de aplicação: quatro e oito vezes. O experimento foi conduzido em blocos casualizados, seguindo esquema fatorial $5 \times 2$, sendo 3 formulações de fosfito, água pura e sem aplicação e dois intervalos de aplicação. Foram adotadas como testemunha água pura e ausência de aplicação. Os frutos foram colhidos, armazenados em câmara de refrigeração $\left(25 \pm 1^{\circ} \mathrm{C}\right.$ e $80 \pm 5 \%$ UR) e avaliados quanto à incidência e à severidade da antracnose bem como as características físicas e químicas. A aplicação de fosfito de cobre pode controlar a incidência da antracnose em até $38 \%$, e a severidade, em 49,5 \%. As frequências de aplicação dos fosfitos não interferem na intensidade da antracnose. A aplicação de fosfito FCu1 nos cachos de banana 'Prata-Anã', assim como realizar oito aplicações de fosfitos, aumenta a perda de massa fresca. A frequência de aplicação dos fosfitos interferiu nas características químicas dos frutos de banana.

Termos para indexaçao: Colletotrichum musae, severidade, Musa spp., fosfitos, tratamento.

\footnotetext{
${ }^{1}$ Agronomist. PhD in Plant Production in the Semi-Arid Region of Brazil, Department of Agricultural Sciences, UNIMONTES. Janaúba-MG, Brazil. Email: marialuisamendes@yahoo.com.br(ORCID 0000-0002-7207-7299)

${ }^{2}$ Agronomy undergraduate student, State University of Montes Claros. Montes Claros-MG. Brazil. Email: gsamuelgustavo1@gmail.com ${ }^{\text {(ORCID }}$ 0000-0002-7284-6705)

${ }^{3} \mathrm{PhD}$, Professor at the Department of Agricultural Sciences, UNIMONTES, Janaúba-MG. Brazil. Email: edson.mizobutsi@unimontes.br(ORCID 0000-0003-2581-8143); gisele.mizobutsi@unimontes.br (ORCID 0000-0001-6953-4332) juceliandy@yahoo.com.br (ORCID 0000-0003-3964-4906).

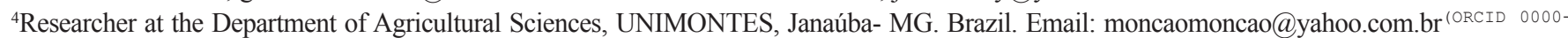
0002-2767-5804)
} 


\section{Introduction}

Anthracnose is a disease caused by Colletotrichum musae and stands out among the various rots that affect banana after harvest, (Berk. and MA Curtis) Arx (MAQBOOL et al., 2010; ALEMU, 2014), causing losses that can reach up to $80 \%$ when fruits are not treated (BILL et al., 2014). C. musae infections occur in the field from the initial stage of fruit development and the fungus remains quiescent until fruit maturation (SIVAKUMAR; BAUTISTA-BAÑOS, 2014). Thus, losses occur mainly for traders and consumers who need to discard damaged fruits. Diseased fruits become poorly presentable and unsuitable for marketing, since there is formation of dark and depressed lesions on fruit peel on which under conditions of high humidity, fungus manifestations can be observed (GARCIA and COSTA, 2000).

Anthracnose control in bananas is an essential component of post-harvest fruit quality (SAGOUA et al. 2011). Control measures that prevent anthracnose infection and development play an important role in prolonging the shelf life of fruits during storage (MAQBOOL et al., 2010). Thus, the control of post-harvest diseases starts with control in the field, harvest and transport. There are several management methods that can be initiated yet in the field, especially cultural control (FERNANDES et al., 2019; VENTURA and HINZ, 2002).

The use of fungicides is the main method for the chemical control of anthracnose in bananas; however, due to the growing consumer demand for fruits produced under environmental-friendly management practices, taking into account the health of applicators and consumers, it is necessary to seek alternatives to the use of fungicides to control phytopathogens (VILAPLANA et al., 2018). Among several alternative control methods, the use of phosphites has been studied by several researchers (OLIVEIRA et al., 2016; DUTRA et al. 2018; FONTANA et al., 2018). This is due to the fact that these products, in addition to having an effect on diseases, also have high phosphorus percentage in their formulations, which allows improving plant nutrition, growth and development (BRACKANN et al., 2008).

Phosphites can act directly, inhibiting the germination of the fungal spore, penetration into the plant, inhibiting mycelial growth and sporulation. Indirectly, it stimulates the metabolism involved in plant resistance, in the production of lignin, phytoalexin and hydrolytic enzymes (BRACKMANN et al., 2008).

Phosphites have been shown to be effective in controlling diseases in various pathosystems, such as rust and downy mildew in grape, rust and powdery mildew in wheat, downy mildew in soy, anthracnose in guavas and rot in apples and peaches (SÔNEGO; GARRIDO, 2005; SAUTTER et al ., 2011; PEREIRA et al., 2010; GOMES, et al., 2016; SANTOS et al., 2018; SILVA et al., 2016).
In view of various evidences of the potential of using phosphites in disease control, the aim of this study was to evaluate phosphite formulations associated with different pre-harvest application intervals on the development of anthracnose in 'Prata-Anã' banana and its effect on the physical and chemical characteristics of fruits.

\section{Material and methods}

The experiment was carried out in a commercial "Prata anã" banana tree orchard, with five years of cultivation in the municipality of Nova Porteirinha Minas Gerais. The farm is located at $15^{\circ} 41$ '21.4 "S and $43^{\circ} 16^{\prime} 23.3^{\prime \prime} \mathrm{W}$ and $500 \mathrm{~m}$ a.s.l. The average annual rainfall is $800 \mathrm{~mm}$, and based on the international Köppen classification, the climate is Aw type (tropical savanna) (ANTUNES, 1986).

Plants used in the test were selected after the emission of the second hand in bunches. To prepare solutions, phosphate was diluted in water and then placed in manual backpack sprayer with capacity of 20 liters. Treatments consisted of: $\mathrm{FCu} 1\left(4 \% \mathrm{Cu}+20 \% \mathrm{P}_{2} \mathrm{O}_{5}\right)-1.5$ mL. $\mathrm{L}^{-1}$ of water, $\mathrm{FCu} 2\left(4 \% \mathrm{Cu}+22 \% \mathrm{P}_{2} \mathrm{O}_{5}\right)-1.5 \mathrm{~mL} \cdot \mathrm{L}^{-1}$ of water, FK $\left(42 \% \mathrm{P}_{2} \mathrm{O}_{5}+27.7 \% \mathrm{~K}_{2} \mathrm{O}\right)-1.5$ grams. $\mathrm{L}^{-1}$ of water, pure water and no application. Solutions were sprayed on bunches and controls were sprayed only with pure water without application of treatments.

The experiment was carried out in randomized blocks in a $5 \times 2$ factorial scheme (FCu1, FCu2, FK, pure water, no application and two application frequencies). For bunches that received four applications, the application interval was every 30 days and those that received eight applications, the interval was every 15 days, corresponding to 4 months in both application frequencies. Four replicates were used with two useful plants per plot.

Bunches were harvested according to criteria recommended by the Brazilian Program for Horticulture Modernization and Integrated Production (2006) for banana fruits of the 'Prata' subgroup, whose harvest pattern is $32 \mathrm{~mm}$ in diameter on fruits of the second hand for high-quality category fruits.

After harvesting, the second and third hands of each bunch of treated plants were selected and packed in plastic boxes and transported to the Laboratory of Post-harvest Pathology. Hands were subdivided into bouquets of three fruits, washed in neutral detergent solution $\left(3 \mathrm{~mL} . \mathrm{L}^{-1}\right)$, rinsed and placed on the bench to dry.

After drying, part of fruits was inoculated with C. musae spores and the other part remained without inoculation. Inoculation was performed by the method of wounding the fruit epidermis with the aid of $5 \mathrm{~mm} \times 0.23$ $\mathrm{mm}$ needle. Then, the latex was removed with the aid of cotton and $5 \mu \mathrm{L}$ of the spore suspension at concentration of 2.5105 spores. $\mathrm{mL}^{-1}$ were deposited on the wound. 
Inoculated fruits and those naturally infected in the field were identified according to treatment received in the field, being subsequently stored in refrigerated chamber at temperature of $25^{\circ} \mathrm{C} \pm 1{ }^{\circ} \mathrm{C}$ and relative humidity of $85 \%$ for 12 days.

Anthracnose intensity in fruits was assessed by incidence and severity. Incidence was obtained by the number of diseased fruits per repetition, which values were expressed as percentage per treatment. For severity, the diagrammatic scale developed by Moraes et al. (2008) with disease severity ranging from 0.5 to $64 \%$ was used. Results were used to calculate the area under the disease progress curve (AUDPC) and area under the severity progress curve (AUSPC) according to formula developed by Shaner and Finney (1977). Assessments were carried out every three days for 12 days. After this period, fruits were removed from the refrigerated chamber and submitted to physical and chemical analyses. The following analyses were carried out:

Fresh weight loss: Each bouquet was weighed on GEHAKA electronic scale, model BK6000, with capacity of $6100 \mathrm{~g}$ and accuracy of $0.01 \mathrm{~g}$, on the day of storage and after the removal of fruits from the refrigerated chamber. Fresh mass loss was determined by the difference between the initial mass of the bouquet and after 12 days of storage. Results were expressed in $\%$.

Soluble solids (SS): Soluble solids (SS) were quantified after crushing the pure pulp in mixer. An aliquot was taken from the pulp for direct reading in digital Reichert bench refractometer (AR200) with automatic temperature compensation. After reading, the refractometer provided the results in ${ }^{\circ}$ Brix, which corresponds to grams of sucrose per $100 \mathrm{~g}$ of solution and can, in general, be used as grams of soluble solids per 100 $\mathrm{g}$ of solution (CARVALHO et al., 1990).

pH: Hydrogen potential $(\mathrm{pH})$ was determined according to methodology of the Association of Official Analytical Chemistry - AOAC (1992). An amount corresponding to $10 \mathrm{~g}$ of sample was weighted and diluted in $90 \mathrm{~mL}$ of distilled water and homogenized in mixer. The $\mathrm{pH}$ was measured using digital $\mathrm{pH}$ meter, calibrated with buffer solution with $\mathrm{pH}$ equal to 7 and buffer solution with $\mathrm{pH}$ equal to 4 .

Titratable acidity (TA): Titratable acidity was determined by volumetric titration with $0.1 \mathrm{~N} \mathrm{NaOH}$ solution using methodology of the Association of Official Analytical Chemistry (AOAC, 1992). An amount corresponding to $10 \mathrm{~g}$ of pulp was weighed and diluted in $90 \mathrm{~mL}$ of distilled water, homogenized with the aid of mini processor and added of 3 drops of 1\% phenolphthalein, used as indicator. Titration with sodium hydroxide was carried out with constant agitation until pink color was obtained for 30 seconds. Results were expressed in $g$ of malic acid per $100 \mathrm{~g}$ of pulp $^{-1}$.

Fruit firmness: Fruit firmness was determined with a Brookfield analog bench fruit penetrometer, model CT3 $10 \mathrm{~K}$, being measured by the penetration force necessary for a tip of $4 \mathrm{~mm}$ in diameter to penetrate the equatorial region of the unpeeled fruit at depth of $8 \mathrm{~mm}$. Results were expressed in Newton $(\mathrm{N})$.

Data obtained were submitted to analysis of variance and through the $\mathrm{F}$ test, the significance of the interactions among factors tested was verified, with subsequent unfolding for significant results. Mixed models were applied to variables, since there are effect factors in data. Tukey's 5\% test was used for treatments and Student's t test was used for different application frequencies. In the data analysis processing, the SISVAR software was used (FERREIRA, 2008).

\section{Results and discussion}

The Area Under the Disease Progress Curve (AUDPC) was not influenced by the interaction between application frequency and phosphite formulations for both inoculated fruits and those naturally infected in the field. For both, the isolated effect of phosphite formulations was significant. Table 01 shows the results obtained for inoculated fruits and those naturally infected in the field.

Table 1 - Area under the disease progress curve (AUDPC) in "Prata anã" banana fruits naturally infected in the field (NIF) and those inoculated with Colletotrichum musae spores and submitted to different phosphite formulations at different application frequencies.

\begin{tabular}{lll}
\hline Treatments & AUDPC & \\
FCu 1 & NIF & Inoculated \\
FCu 2 & $250.00 \mathrm{a}$ & $297.50 \mathrm{a}$ \\
FK & $225.00 \mathrm{a}$ & $256.25 \mathrm{a}$ \\
Water & $355.00 \mathrm{~b}$ & $377.30 \mathrm{~b}$ \\
Control & $377.00 \mathrm{~b}$ & $413.80 \mathrm{~b}$ \\
\hline CV $(\%)$ & $380.00 \mathrm{~b}$ & $408.20 \mathrm{~b}$ \\
\hline
\end{tabular}

Means followed by different letters in columns differ statistically from each other using the Tukey test at $5 \%$ probability. 
The incidence of fruits with quiescent anthracnose infections detected after the application of FCu 1 and $\mathrm{FCu} 2$ were reduced by up to $34 \%$ and $41 \%$, respectively, for fruits naturally infected in the field and $38 \%$ and $28 \%$ for inoculated ones.

When assessing the anthracnose incidence in bananas treated with FK, results obtained did not differ statistically from control. The use of FK in the control of post-harvest diseases has greater effect on severity, being less efficient in reducing incidence. Work carried out by Fischer et al. (2016) demonstrates this behavior. The authors observed $95.2 \%$ anthracnose incidence in guava after eight days of storage with the use of FK.

Chitarra and Chitarra (2005) reported that K can act in enzymatic processes and in the preservation of integrity, which may contribute to the formation of fruits more resistant to rot. However, this phenomenon was not observed in the Colletotrichum musae x 'Prata-Anã' banana fruit pathosystem.

Potassium phosphite is a product frequently used in the management of plant diseases including in tree species, being indicated in the control of oomycetos such as Pytium spp., Phytophthora spp. and fungi that cause stem, root, trunk and fruit rot (Mc Donald et al., 2001).

For the anthracnose AUSPC, significance was found only for the isolated phosphite formulation for both fruits naturally infected in the field and for those inoculated (Table 02). FCu2 was the formulation that promoted the greatest reduction in disease severity, inhibiting AUSPC by $46 \%$ and $49.5 \%$ in fruits naturally infected in the field and those inoculated, respectively (Table 02).

Table 2 - Area under the severity progress curve (AUSPC) in 'Prata anã' banana fruits naturally infected in the field (NIF) and those inoculated with Colletotrichum musae spores and submitted to different phosphite formulations at different application frequencies.

\begin{tabular}{lll}
\hline Treatments & AUSPC & \\
FCu1 & NIF & Inoculated \\
FCu2 & $93.0 \mathrm{ab}$ & $137.0 \mathrm{ab}$ \\
FK & $74.0 \mathrm{a}$ & $96.33 \mathrm{a}$ \\
Water & $127.3 \mathrm{bc}$ & $170.0 \mathrm{bc}$ \\
Control & $137.3 \mathrm{c}$ & $184.83 \mathrm{c}$ \\
\hline CV $(\%)$ & $137.0 \mathrm{c}$ & $191.0 \mathrm{c}$ \\
\hline
\end{tabular}

Means followed by different letters in columns differ statistically from each other using the Tukey test at 5\% probability.

The reduction in anthracnose severity in fruits treated with copper phosphite occurred due to the direct action of copper on the pathogen. $\mathrm{Cu}$ is in the composition of many fungicides and syrups used in integrated disease management. According to Matiello and Almeida (2006), copper-based fungicides, in addition to good efficiency, have tonic-nutritional effects, greater leaf retention, increased productivity and improved final fruit quality.

The beneficial effect of using copper phosphite in disease control has been observed in several other pathosystems. The result found in the present study confirms the existing literature data. Melo et al. (2016) obtained reduction in the Fusarium guttiforme incidence in pineapples with application of copper phosphite. Dantas et al. (2018) observed inhibition in the development of Alternaria sp., C. gloeosporioides, Fusarium sp., Geotrichum sp. and Lasiodiploidia theobromae fungi using the same copper phosphite formulation. There is no evidence that plants benefit from phosphite as source of phosphorus; however, the elements that accompany this molecule in phosphite-based products such as zinc (zinc phosphite) can act in nutrition, providing this element to plants (DALIO et al., 2012) and having direct action on the pathogen (SILVA et al., 2016). In addition, micronutrients act as cofactors for enzymes involved in the synthesis of phenolic compounds (SILVA et al., 2008).

The application of FK provided low efficiency in the anthracnose control, and results obtained were similar to those of control. The low efficiency of potassium phosphite was also observed by Ferraz et al. (2016). Potassium phosphite showed low anthracnose control in guava when compared with $\mathrm{Zn}$ and $\mathrm{Mg}$ phosphites. According to Lopes et al. (2017), potassium phosphite has no effect on anthracnose control in papaya.

The results found in literature on the use of potassium phosphite in the control of plant diseases have been very contradictory. Oliveira et al. (2016) stated that potassium phosphite inhibited $28 \%$ anthracnose in 'PrataAnã' banana fruits, but this result is much lower compared to fungicide. Dutra et al. (2018) found that different potassium phosphite sources were effective in reducing anthracnose severity in yellow passion fruit inoculated with C. gloeosporioides.

In the composition of phosphates, $\mathrm{P}_{2} \mathrm{O}_{5}$ concentration can also influence the fungitoxic and fungistatic activity of products. However, contradictory results can be observed 
with the use of $\mathrm{P}_{2} \mathrm{O}_{5}$ concentrations. $\mathrm{FCu} 2$ formulation has $22 \% \mathrm{P}_{2} \mathrm{O}_{5}$ in its composition, while $\mathrm{FK}$ has $42 \% \mathrm{P}_{2} \mathrm{O}_{5}$ and reduction in anthracnose development was greater using FCu2 when compared to FK. Pereira et al. (2012) obtained reduction in downy mildew severity in grapes when applying phosphite doses with higher $\mathrm{P}_{2} \mathrm{O}_{5}$ concentrations (2.1 $\mathrm{g} \mathrm{L}^{-1}$ of $\mathrm{P}_{2} \mathrm{O}_{5}$ ).

\section{Physical and chemical characteristics}

When analyzing fresh weight loss of fruits, no interaction was found between concentrations and phosphite formulations in inoculated fruits and in those naturally infected in the field. For both, there was only the isolated effect from phosphite source (Tables 3) or application frequency (Table 4).

Table 3 - Fresh mass loss (\% FML) of 'Prata-Anã'banana fruits naturally infected in the field (NIF) and those inoculated with Colletotrichum musae spores and submitted to different phosphite formulations.

\begin{tabular}{lll}
\hline \multirow{2}{*}{ Phosphite source } & FML & \\
\cline { 2 - 3 } & NIF & Inoculated \\
\hline FCu 1 & $7.01 \mathrm{~b}$ & $7.3 \mathrm{~b}$ \\
FCu2 & $6.23 \mathrm{ab}$ & $6.39 \mathrm{ab}$ \\
FK & $6.14 \mathrm{ab}$ & $6.5 \mathrm{ab}$ \\
Water & $4.84 \mathrm{a}$ & $4.93 \mathrm{a}$ \\
Control & $5.28 \mathrm{a}$ & $5.53 \mathrm{a}$ \\
\hline CV $(\%)$ & 31.02 & 32.01 \\
\hline
\end{tabular}

Means followed by different letters in columns differ statistically from each other using the Tukey test at $5 \%$ probability.

Table 4- Fresh mass loss (\% FML) of 'Prata-Anã'banana fruits naturally infected in the field (NIF) and those inoculated with Colletotrichum musae spores and submitted to different phosphite application frequencies.

\begin{tabular}{lll}
\hline \multirow{2}{*}{ Application frequency } & FML & \\
\cline { 2 - 3 } & NIF & Inoculated \\
\hline 4 & $5.50 \mathrm{a}$ & $5.34 \mathrm{a}$ \\
8 & $6.75 \mathrm{~b}$ & $6.47 \mathrm{~b}$ \\
\hline $\mathrm{CV}(\%)$ & 32.01 & 31.02 \\
\hline
\end{tabular}

Means followed by different letters in columns differ statistically from each other by the t test at $5 \%$ probability.

The greatest weight losses were obtained by treatment in which FC1 was applied, both to inoculated fruits and those naturally infected in the field. This result may be associated with the lower $\mathrm{P}_{2} \mathrm{O}_{5}$ content of this treatment when compared to the others. According to Dechen and Nachtigall (2007), phosphorus is associated with fruit quality. The effect of phosphorus on post-harvest fruit physiology can be attributed to its role as a component of phospholipids, one of the main constituents of the cell membrane (KNOWLES et al. 2001). Treatments using $\mathrm{FCu} 2$ and FK did not differ statistically from controls both in inoculated fruits and in those naturally infected in the field.

The fresh weight loss of fruits is mainly associated with loss of water caused by both transpiration and respiration, which is higher when fruits are stored at high temperatures and / or low relative humidity (BOTREL et al., 2001). This mass loss is also accentuated the greater the ripeness degree of fruits, reaching excessively high levels during fruit senescence, when it is no longer suitable for marketing. The physical and chemical analyses of fruits in the present experiment were carried out at stages 6 and 7 of maturation, in which fruits showed maximum ripeness.
These results differ from those obtained by Araújo (2017) in an experiment with guava, where the author found that the lowest FML was obtained in control in relation to fruits treated with $\mathrm{Ca}$ and $\mathrm{K}$ phosphite.

Results obtained for inoculated fruits are similar to those obtained for fruits naturally infected in the field, both for the effect of phosphite sources and application frequency (Tables 3 and 4).

According to table 04 , fruits submitted to phosphite application in the frequency of 15 days presented higher FML both in fruits naturally infected in the field and inoculated ones. Fruits submitted to this application frequency received twice as many phosphites at the end of the experiment, so it is possible that phosphite has increased the transpiration rate of fruits, increasing FML.

For soluble solids, significance was found only for application frequency (Table 05). It is possible to verify that in the application frequency of every 15 days, the SS content was higher, showing that fruit "sweetness" is greater when compared with fruits applied every 30 days. Some authors working with different fruits reported that the SS content does not change due to the phosphite application (FISCHER, 2016, LOPES et al. 2017; DAMBROS et al. 2016). 
Table 5 - Soluble solids content of 'Prata-Anã' bananas fruits naturally infected in the field those inoculated with Colletotrichum musae spores and submitted to different phosphite application frequencies.

\begin{tabular}{ll}
\hline Application frequency & SS \\
\hline 4 & $24.31 \mathrm{~b}$ \\
8 & $24.69 \mathrm{a}$ \\
\hline $\mathrm{CV}(\%)$ & 3.04 \\
\hline
\end{tabular}

Averages followed by different letters in columns differ statistically from each other by the $t$ test at $5 \%$ probability.

Banana is a fruit with high starch content when green and, as it ripens, starch is broken down into sugars to be used in the respiration process, increasing the soluble solids content (PIMENTEL et al., 2010).

Soluble solid attribute is of great importance both for fresh consumption and for the food industry. According to Paiva et al., (1997), high soluble solids content in the raw material imply less sugar addition, shorter water evaporation time, less energy expenditure and higher product yield, resulting in greater processing savings. Soluble solids are also important in determining fruit quality as indicator of the sugar content together with acids, vitamins, amino acids and some pectins (STOVER; SIMMONDS, 1987; LOBO et al., 2005).
For variables $\mathrm{pH}$ and titratable acidity (TA) in fruits naturally infected in the field, no interaction among factors tested was observed. Significance was found only for the application frequencies of products (Tables 6 and 7 respectively). It was observed that bunches submitted to application of 30 days, $\mathrm{pH}$ remained a little higher than those submitted to application of 15 days (Table 7). Consequently, the lowest TA was obtained with application every 30 days (Table 8).

Table 6- $\mathrm{pH}$ of 'Prata-Anã' bananas fruits naturally infected in the field and those inoculated with Colletotrichum musae spores and submitted to different phosphite application frequencies.

\begin{tabular}{ll}
\hline Application frequency & $\mathbf{p H}$ \\
\hline 4 & $4.81 \mathrm{a}$ \\
8 & $4.75 \mathrm{~b}$ \\
\hline CV (\%) & 2.16 \\
\hline
\end{tabular}

Averages followed by different letters in columns differ statistically from each other by the $\mathrm{t}$ test at $5 \%$ probability.

Table 7- Titratable acidity of 'Prata-Anã' bananas fruits naturally infected in the field and those inoculated with Colletotrichum musae spores and submitted to different phosphite application frequencies.

\begin{tabular}{ll}
\hline Application frequency & TA \\
\hline 4 & $0.48 \mathrm{~b}$ \\
8 & $0.53 \mathrm{a}$ \\
\hline $\mathrm{CV}(\%)$ & 9.68 \\
\hline
\end{tabular}

Averages followed by different letters in columns differ statistically from each other by the $t$ test at $5 \%$ probability.

Table 8 - pH of 'Prata-Anã' bananas fruits naturally infected in the field and those inoculated with Colletotrichum musae spores and submitted to different phosphite application frequencies in pre-harvest bunches.

\begin{tabular}{lll}
\hline \multirow{2}{*}{ Phosphite formulations } & \multicolumn{2}{c}{ Phosphite application frequency (number of applications) } \\
\cline { 2 - 3 } & $\mathbf{4}$ & $\mathbf{8}$ \\
\hline FCu 1 & $4.77 \mathrm{Aa}$ & $4.72 \mathrm{aA}$ \\
FCu2 & $4.71 \mathrm{Aa}$ & $4.80 \mathrm{aA}$ \\
FK & $4.64 \mathrm{Ab}$ & $4.76 \mathrm{aA}$ \\
Water & $4.78 \mathrm{Aa}$ & $4.68 \mathrm{aA}$ \\
Control & $4.77 \mathrm{Aa}$ & $4.66 \mathrm{aA}$ \\
\hline CV $(\%)$ & 2.53 &
\end{tabular}

Means followed by different lowercase letters in columns and uppercase letters in rows statistically differ from each other by the Tukey test at $5 \%$ probability. 
During banana ripening, fruit $\mathrm{pH}$ decreases due to the chemical transformations, and other authors observed values from 4.2 to 5.0 in mature fruits, varying with treatment used (SIQUEIRA et al., 2017; SIQUEIRA et al., 2010; SIQUEIRA et al., 2017). According to Pimentel et al. (2010), the decrease in titratable acidity is due to the lower production of organic acids, compared to their consumption during the respiratory process, which are used in respiration for ATP production, reducing fruit acidity.

Titratable acidity ranged on average from 0.48 to $0.53 \mathrm{~g}$ of malic acid. $100 \mathrm{~g}$ of pulp $^{-1}$ between application frequencies (Table 7). These results are in agreement with those obtained by other authors. Castricini et al., (2015) found 0.47 (mg malic acid.100 g pulp) in 'Prata-Anã' banana fruits at stage 6 of maturation. Oliveira et al. (2016) obtained 0.54 (mg malic acid.100 g pulp) in 'Prata-Anã' banana over the storage period. Oliveira et al., (2013) found 0.54 (mg malic acid.100 g pulp) in 'Prata-Anã' and 'BRS Platina' banana cultivars.

Research results associating the influence of phosphites on TA of fruits were found by Pereira et al. (2012) working with 'Merlot' grapes treated with potassium phosphite. The authors observed that the soluble solids content, $\mathrm{pH}$ and titratable acidity of wine must did not change with the application of potassium phosphites in fruits; however, it was found that these values were superior to control. Pereira et al. (2010) also found no differences in the analytical quality of phosphitetreated berries. Amaral et al. (2017) found that calcium and potassium phosphites did not influence the titratable acidity of papaya.

Acidity is attributed to the presence of organic acids dissolved in the vacuoles of cells, the organic acid contents in the majority of fruits decrease with ripening (CHITARRA and CHITARRA, 2005). In bananas, according to Pinheiro (2018), fruit acidity increases during ripening, with malic, citric and oxalic organic acids being the main acids found in the pulp. With advancing maturation and senescence, acidity decreases, presumably due to its use as respiratory substrates.

In the $\mathrm{pH}$ of fruits naturally infected in the field, significant interaction was observed between phosphite sources and application frequency (Table 08).

It was observed that the application frequencies did not influence the $\mathrm{pH}$ of fruits. When analyzing phosphite formulations, it was found that when applying FK at frequency of every 30 days, the $\mathrm{pH}$ of fruits remained higher. Possibly, there was reduction in fruit ripening because in green fruits, pulp $\mathrm{pH}$ is higher.

Fernandes et al. (2019) found $\mathrm{pH}$ values of 5.5 in fruits harvested in the pre-climacteric stage and after fruit ripening, there was $\mathrm{pH}$ reduction to 4.3. Santos et al. (2018) found $\mathrm{pH}$ variation from 5.38 to 4.78 over the ripening period of 'Prata-Anã' bananas .

\section{Conclusions}

Copper phosphite significantly reduces anthracnose incidence and severity in both inoculated and uninoculated fruits.

The application frequency of phosphites does not affect anthracnose intensity.

The application of FCu1 phosphite in 'Prata-Anã' banana bunches increases fresh mass loss.

The physical and chemical characteristics of fruits were influenced by the application frequency of phosphites.

\section{Acknowledgments}

The authors would like to thank CAPES and FAPEMIG for financial support.

\section{References}

ALEMU, K. Importância e espectro de patógenos da podridão da coroa de banana na cidade de Jimma, sudoeste da Etiópia. Jornal de Biologia, Agricultura e Saúde, New York, v.4, n.233, p.106-111, 2014.

AMARAL, D.D.; MONTEIRO, A.L.R.; SILVA da E.I.; LINS, S.R.O. de; OLIVEIRA, S.M.A. de. Frequency of quiescent fungi and post-harvest alternative management of stem end rot in Papaya. Revista Caatinga, Mossoró, v.30, n.3, p.786-793, 2017.

ANTUNES, F.Z. Caracterização climática do estado de Minas Gerais: climatologia agrícola. Informe Agropecuário, Belo Horizonte, v.12, p.9-13, 1986.

AOAC - Association of Official Analytical Chemistry. Official methods of analysis of the Association of Official Chemistry, Washington, 1992. p.1115.

ARAÚJO, M.B. Influência de fosfitos, hidrotermia e película de amido na qualidade pós-colheita de goiabas. 2017. Monografia (Graduação em Agronomia) - Universidade de Brasília, Brasília, 2017.

BILL, M.; SIVAKUMAR, D.; KORSTEN, L.; THOMPSON, A.K. The efficacy of combined application of edible coatings and thyme oil in inducing resistance components in avocado (Persea americana Mill.) against anthracnose during post-harvest storage. Crop Protection, Bedford, n.64, p.159-167, 2014. 
BRACKMANN, A.; GIEHL, R.F.H.; SESTARI, I.; WEBE, A.; PINTO, J.A.V.; EISERMANN, A.C. Rot control on cold stored 'Fuji' apples with pre and postharvest treatments with phosphites and benzalkonium chloride. Revista da FZVA, Uruguaiana, v.15, n.2, p.35-43, 2008.

BOTREL, N.; SILVA, O.F.; BITTENCOURT, A.M. Banana pós-colheita: procedimentos pós-colheita. Brasília: Embrapa Frutas do Brasil, 2001.

CARVALHO, C.R.L.; MANTOVANI, D.M.B.; CARVALHO, P.R.N.; MORAES, R.M.M. Análises químicas de alimentos. Campinas: ITAL, 1990. 121p.

CASTRICINI, A.; SANTOS, LO.; DELIZA, R.; COELHO, E.F.; RODRIGUES, M.G. Caracterização pós-colheita e sensorial de genótipos de bananeiras tipo Prata. Revista Brasileira Fruticultura, Jaboticabal, v.37, n.1, p.27-37,1 2015.

CHITARRA, M.I.F.; CHITARRA, A.B. Pós-colheita de frutas e hortaliças: fisiologia e manuseio. 2.ed. Lavras: UFLA, 2005. $785 \mathrm{p}$.

DALIO, R.J.D.; RIBEIRO JUNIOR, P.M.; RESENDE, M.L.V.; SILVA, A.C.; BLUMER, S..PEREIRA, V.F.. OSSWALD, W..PASCHOLATI, S.F. O triplo modo de ação dos fosfitos em plantas. Revisão Anual de Patologia de Plantas, Passo Fundo, v.20, n.1, p.206-243, 2012.

DAMBROS, D.; MONTEIRO, A.L.R.; MELO, A.P.; LINS, S.R.O.; OLIVEIRA, S.M.A. Caracterização epidemiológica e fosfitos no manejo da podridão por Aspergillus niger em uva de mesa. Agrária - Revista Brasileira de Ciências Agrárias, Recife, v.11, n.3, p.171177, 2016.

DANTAS, A.M.de M.; NASCIMENTO, S.R.de C.; CRUZ, B.L.S.da; SILVA, F.H.A.da, AMBRÓSIO, M.M.de Q.; SENHOR, R.F. Alternative control of post-harvest diseases in Tainung 1 papaya. Pesquisa Agropecuária Tropical ,Goiânia, v.48, n.1, p.29-35,

DECHEN, A.R.; NACHTIGALL, G.R. Elementos requeridos à nutrição de plantas. In: NOVAIS, R.F.; ALVAREZM V.H.; BARROS, N.F.; FONTES, R.L.; CANTARUTTI, R.B.; NEVES, J.C.L.(Ed.). Fertilidade do solo. Viçosa: Sociedade Brasileira de Ciência do Solo, 2007. p.91-132.
DUTRA, J.B.; BLUM, L.E.B.; LOPES, L.F.; CRUZ, A.F.; UESUG, C.H. Use of hot water, combination of hot water and phosphite, and 1MCP as post harvest treatments for passion fruit (Passiflora edulis f.flavicarpa) reduces anthracnose and does not alter fruit quality. Horticulture, Environment, and Biotechnology, v.59, n.6, p.847-856, 2018.

FERNANDES, M.B.; MIZOBUTSI, E.H.; RODRIGUES, M.L.M.; RIBEIRO, R.C.F.; MIZOBUTSI, G.P.; PINHO, D.B. Bagging time of 'Prata-anã' banana regarding anthracnose control. Revista Brasileira de Fruticultura, Jaboticabal, v.41, n.1, 2019.DOI: Disponível em: http:// dx.doi.org /10.1590/0100-29452019066.

FISCHER, I.H.; PALHARINI, M.C.A.; FILETI, M.de S.; NOGUEIRA JÚNIOR, A.F.; PARISI, M.C.M. Tratamentos alternativos no controle da antracnose e sobre a qualidade de goiabas 'Pedro Sato'. Summa Phytopathologica, Botucatu, v.42, n.4, p.333-339, 2016.

FERRAZ, D.M.M.; BLUM, L.E.B.; BARRETO, M.L.A.; UESUGI, C.H.PEIXOTO, J.R.; CRUZ, A.F. Fosfito no controle da antracnose e qualidade pós-colheita de goiaba em cultivo convencional e orgânico. Revista de Agricultura, Piracicaba v.91, n.3, p.249 - 264, 2016.

FERREIRA, D.F. SISVAR: Um programa para análises e ensino de estatística. Revista Symposium, Lavras, v.6, p.36-41, 2008.

FONTANA, D.C.; KULCZYNSKI, S.M.; TREVISAN, R.; PINHEIRO, M.V.M.; DIEL, M.I.; PINHEIRO, M.O. Manejo de controle de patógenos durante o desenvolvimento e na pós-colheita de frutos de pessegueiro. Cultura Agronômica, Ilha Solteira, v.27, n.1, p.124-140, 2018.

GARCIA, A., COSTA, J.N.M. Principais doenças fúngicas da bananeira em Rondônia: sintomatologia e controle. Porto Velho: EMBRAPA-CPAF, 2000.

GOMES, R. dos S.S.; DEMARTELAERE, A.C.F.; NASCIMENTO, L.C.do; MACIEL, W.O.; WANDERLEY, D.B.N.da S. Bioatividade de indutores de resistência no manejo da antracnose da goiabeira (Psidium guajava L.). Summa Phytopathologica, Botucatu, v.42, p.149-154, 2016.

L KNOWLES, M.; TRIMBLE, R., KNOWLES, R.N. Phosphorus status affects postharvest respiration. Membrane permeability and lipid chemistry of European seedless cucumber fruit (Cucumis sativusL.). Postharvest Biology and Technology, Amsterdam, v.21, p.179-188, 2001. 
LOPES, L.F.; CRUZ, A.F.; BARRETO, M.L.DE A.; VASCONCELOS, T.M.M.; BLUM, L.E.B. Post-harvest treatment with $\mathrm{Ca}$-phosphite reduces anthracnose without altering papaya fruit quality. The Journal of Horticultural Science and Biotechnology, v.93, n.3, p.272-278, 2017.

LOBO, M.G.GONZALES, M.; PEÑA, A.; MARRERO, A. Effects of ethylene exposure temperature on shelf life, compositions and quality of artificially ripened bananas (Musa acuminata AAA, cv.'Dwarf Cavendish'). Food Science and Technology International, London, v.11, n.2, p.99-105, 2005.)

MAQBOOL, M.; ALI, A.; RAMACHANDRAN, S.; SMITH, D.R. Control of postharvest anthracnose of banana using a new edible composite coating. Crop Protection, Guildfor, v.29, n.10, 2010.

MATIELlO, J.B.; ALMEIDA, S.R. A ferrugem do cafeeiro no Brasil e seu controle. Varginha: MAPA/ PROCAFÈ, 2006.104 p.

McDONALD, A.E.; GRANT, B.R.; PLAXTON, W.C. Phosphite (phosphorous acid): its relevance in the environment and agriculture and influence on plant phosphate starvation response. Journal of Plant Nutrition, New York, v.24, n.10, p.1505-1519, 2001.

MELO, L.G.L.; SILVA, E.K.C.; CAMPOS NETO, J.R.M.; LINS, S.R.O.; RODRIGUES, A.A.C.; OLIVEIRA, S.M.A.Indutores de resistência abióticos no controle da fusariose do abacaxi.Pesquisa Agropecuária Brasileira, Brasília, DF, v.51, n.10, p.1703-1709, 2016.

MORAES, W.S.; ZAMBOLIM, L.; LIMA, J.D. Quimioterapia de banana 'Prata anã' no controle de podridões pós-colheita. Arquivos do Instituto Biológico, São Paulo, v.75, n.1, p.79-84, 2008.

OLIVEIRA, C.G.de; DONATO, S.L.R.; MIZOBUTSI, G.P.; SILVA, J.M.; MIZOBUTSI, E.H. Características pós-colheita de bananas 'Prata-anã' e 'BRS platina' armazenadas sob refrigeração. Revista Brasileira de Fruticultura, Jaboticabal, v.35, n.3, p.891-897, 2013.

OLIVEIRA, E.S.; VIANA, F.M.P.; MARTINS, M.V.V. Alternativas a fungicidas sintéticos no controle da antracnose da banana. Summa Phytopathologica, Botucatu, v.42, n.4, p.340-350, 2016.

PAIVA, M.C.; MANICA, I.; FIORAVANCO, J.C.; KIST, H. Caracterização química dos frutos de quatro cultivares e duas seleções de goiabeira. Revista Brasileira de Fruticultura, Jaboticabal, v.19, n.1, p.57-63, 1997.
PBMH \& PIF - Programa Brasileiro para a Modernização da Horticultura \& Produção Integrada de Frutas. Normas de classificação de banana. São Paulo: Ceagesp, 2006.(Documentos, 29) PEREIRA, V.F.; RESENDE, M.L.V.; MONTEIRO, A.C.A.; RIBEIRO JÚNIOR, P.M.; ALBUQUERQUE, M.de.; REGINA, M.A.de.; MEDEIROS, F.C.L. Produtos alternativos na proteção da videira contra o míldio. Pesquisa Agropecuária Brasileira, Brasília, DF, v.45, n.1, p.25-31, 2010.

PEREIRA, V.F.; RESENDE, M.L.V.de; RIBEIRO JÚNIOR, P.M.; REGINA, M.A.; MOTA, R.V.da.; VITORINO, L.R.R. Fosfito de potássio no controle do míldio da videira e características físicoquímicas de uvas Merlot. Pesquisa Agropecuária Brasileira, Brasília, DF, v.47, n.11, p.1581-1588, 2012.

PIMENTEL, R.M.de A.; GUIMARÃES, F.N.; SANTOS, V.M.; RESENDE, J.C.F. de. Qualidade pós-colheita dos genótipos de banana PA42-44 e Prata-Anã cultivados no norte de Minas Gerais. Revista Brasileira de Fruticultura, Jaboticabal, v.32, n.22, p.407-413, 2010.

PINHEIRO, J.M. da S. Avaliação do tratamento hidrotérmico na qualidade e conservação pós-colheita da banana 'Prata-Anã'. 2018. Tese (Doutorado) Programa de Pós-Graduação em Produção Vegetal no Semiárido, Universidade Estadual de Montes Claros, Janaúba, 2018.

SAGOUA, W.; DUCAMP, M.N.; LOISEAU, G.; BELLAIRE, L.de L. Effect of lactoperoxidase system on C. musae. Food Technology Biotechnology, Zagreb, v.49, n.2, p.244-248, 2011.

SANTOS, T.C.; AGUIAR, F.S.; RODRIGUES, M.L.M.; MIZOBUTSI, G.P.; PINHEIRO, J.M.S. Quality of bananas harvested at diferente development stages and subjected to cold storage. Pesquisa Agropecuária Tropical, Goiânia, v.48, n.2, p.90-97, 2018.

SANTOS, S.L.dos; CAMPOS, T.de; DALLACOSTA, N.L; MAZARO, S.M. Potencial de produtos à base de fosfitos no controle de Pythium sp.em condições in vitro. Pesquisa Aplicada \& Agrotecnologia, Guarapuava, v.11, n.1, p.105-110, 2018.

SAUTTER, C.K.; STORCK, L.; RIZZATI, M.R.; MALLMANN, C.A.; BRACKMANN, A. Síntese de trans-resveratrol e controle de podridão em maçãs com uso de elicitores em pós-colheita. Pesquisa Agropecuária Brasileira, Brasília, DF, v.43, p.1097-1103, 2008. 
SILVA, A.C.da; RESENDE, M.L.V..SOUZA, P.E.; PÔSSA, K.F.; SILVA JÚNIOR, M.B .da. Extrato vegetal, fosfito e sulfato de zinco no controle do oídio em eucalipto. Revista Ciência Agronômica, Fortaleza v.47, n.1, p.93100, 2016.

SILVA, I.L.S.S.; RESENDE, M.L.V.; RIBEIRO JÚNIOR, P.M.; COSTA, J.C.B.; CAMILO, F.R.J.C.B.; SALGADO, S.M.L. Efeito de nutrientes combinados com indutores de resistência na proteção contra a vassoura-de-bruxa no cacaueiro. Ciência Agrotecnológica, Lavras, v.32, n.1, p.61-67, 2008 .

SIVAKUMAR, D.; BAUTISTA-BAÑOS, S. A review on the use of essential oils for postharvest decay control and maintenance of fruit quality during storage. Crop Protection, Bedford, v.64, p.27-37, 2014.

SHANER, G.; FINNEY, R.F. The effects of nitrogen fertilization on the expression of show-mildwing in knox wheat. Phytopathology, Saint Paul, v.67, p.1051-1055, 1977.

SIQUEIRA, C.L.; RODRIGUES, M.L.M.; MIZOBUTSI, G.P.; SANTOS, P.G.S.dos.; MOTA, W.F.; MIZOBUTSI, E.H.; OLIVEIRA, G.B.O. Características físico-quimicas, análise sensorial e conservação de frutos de cultivares de bananeira resistentes à Sigatoka-negra. Revista Ceres, Viçosa, MG, v.57, n.5, p.673-678, 2010.
SIQUEIRA, C.L.; ALMEIDA de, H.J.; SERPA, M.F.P.; BATISTA, P.S.C.; MIZOBUTSI, G.P. Atmosfera modificada associada à refrigeração na conservação de frutos de bananas resistentes à Sigatoka Negra. Revista Ciência Agronômica, Fortaleza, v.48, n.4, p.614-624, 2017.

SIQUEIRA, C.L.; LOPES, O.P.; BATISTA, P.S.C.; RODRIGUES, M.L.M.; SERPA, M.F.P.; MIZOBUTSI, G.P.; MOTA, W.F.da. Atmosfera modificada e refrigeração na conservação pós-colheita de bananas 'Tropical' e 'Thap Maeo'. Revista Nativa, Sinop, v.5, n.3, p.157-162, 2017.

SÔNEGO, O.R.; GARRIDO, L. da R. Avaliação da eficácia de algumas marcas comerciais de fosfito de potássio e de fosfonato de potássio no controle do míldio da videira. Bento Gonçalves: Embrapa Uva e Vinho, 2005. 13p. (Circular Técnica, 60).

STOVER, R.H; SIMMONDS, N.W. Bananas. $3^{\text {rd }}$ ed. New York: Longman Scientific \& Technical, 1987.

VENTURA, J.A.; HINZ, R.H. Controle das doenças da bananeira. In: ZAMBOLIM, L.; VALE, F.X.R. do; MONTEIRO, A.J.A.; COSTA, H. (Ed.). Controle de doenças de plantas - Fruteiras. Vicosa: Suprema Gráfica e Editora, 2002. v.2, p.839-937.

VILAPLANA, R.; PAZMIÑO, L.; VALENCIACHAMORRO, S. Control of anthracnose, caused by Colletotrichum musae, on postharvest organic banana by thyme oil. Postharvest Biology and Technology, Amsterdam, v.138, p.56-63, 2018. 